\title{
Climate Change and Health Teenager's Perceptions as a Basis for Interventions
}

\author{
Sulistyawati ${ }^{1}$, Izzatun Nisa ${ }^{2}$ \\ Department of Public Health, Universitas Ahmad Dahlan, Indonesia
}

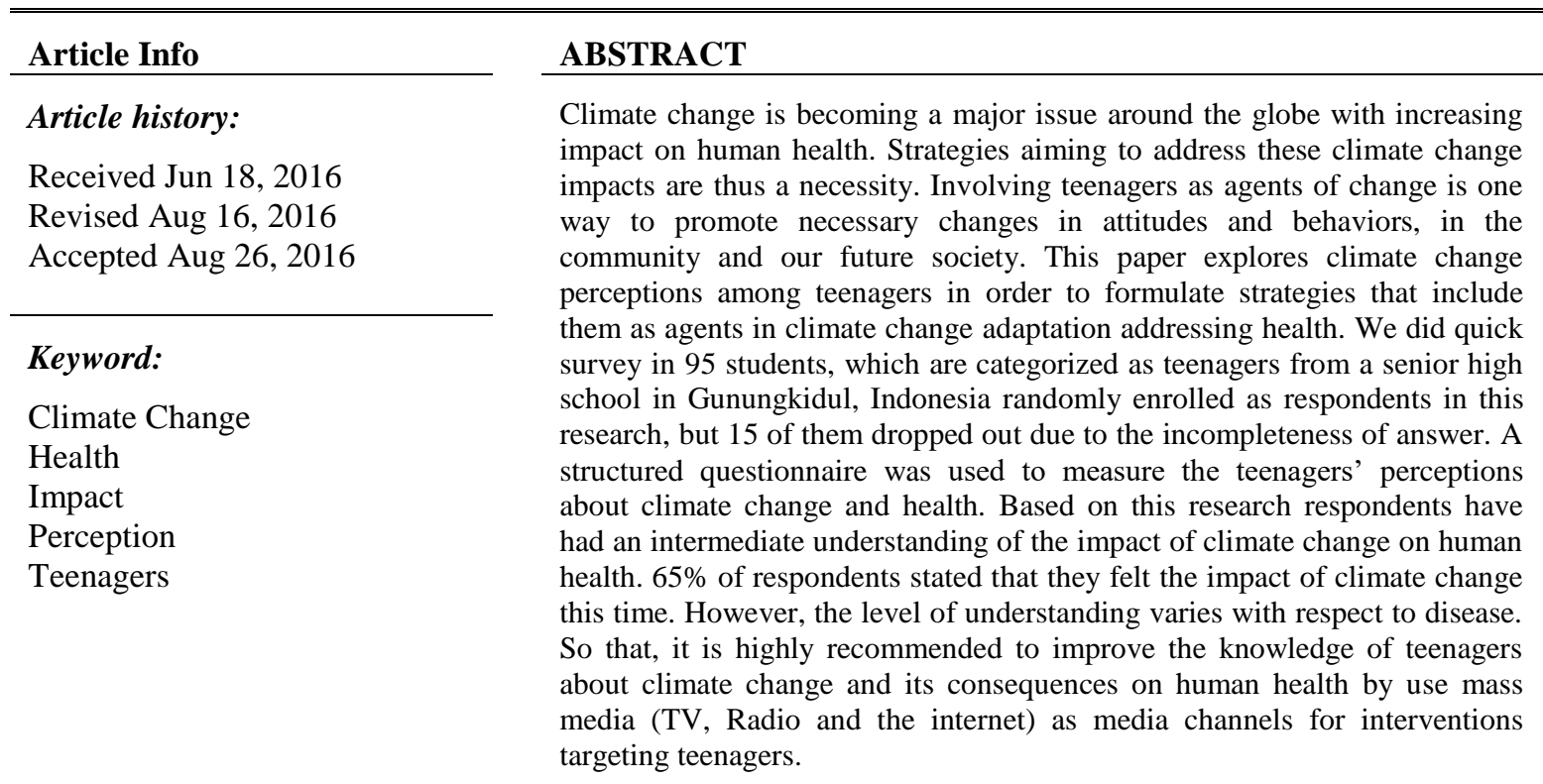

Copyright $@ 2016$ Institute of Advanced Engineering and Science. All rights reserved.

\section{Corresponding Author:}

Sulistyawati,

Department of Public Health Science,

Universitas Ahmad Dahlan,

Street Prof. Dr. Soepomo, Janturan, Umbulharjo, Yogyakarta. Indonesia.

Email: sulistyawatisuyanto@gmail.com

\section{INTRODUCTION}

Climate change has become a concerning problem with undeniable evidence which is driven by human activity. Low and middle income countries will be affected mostly due to the high number of lowincome citizens and thus low adaptive capacity of the citizens and of local governments [1]. As a consequence, adaptive strategies aiming to increase the resilience of these populations are essential to minimize the negative impacts on health and society [2].

The evidence shows that increasing temperatures, high intensity of rain, drought and rising sea levels are an indication that the climate is changing and have a relation to natural disasters, for example high intensity rain potentially triggers landslides and increasing temperature could be causing forest fires [3]. This will affect all aspects of human life (i.e. health, food production etc.) [4] and many diseases, such as respiratory diseases, vector borne diseases, mental disorders and cancer, which are triggered or worsened by a change in climate [5]-[7].

Gunungkidul, Yogyakarta, Indonesia is a district vulnerable to climate change because of its geographical characteristics. The district consists of a coastal area and Limestone Mountains and is susceptible to drought, sea level rise, tornados and to infectious diseases. Drought in Gunungkidul worried triggers food insecurity and malnutrition. Sea level rise endanger populations in coastal areas and affects the 
main source of income, which is fishing. Several mountainous areas in Gunungkidul have experienced tornados and flash floods, which can cause accidental deaths due to falling trees, collapsing houses or landslides. It is also predicted that an increase in temperature in the mountains will trigger mosquitoes to move to higher grounds [8], hence increasing the risk of Gunungkidul to become exposed to several climate sensitive infectious diseases like Malaria and Dengue.

The target sample is teenagers that are young people with age 16-17 years old. Oxford dictionary [9] defined teenagers as "A person aged between 13 and 19 years". Teenagers have similarity meaning with adolescence. World Health Organization defined adolescence as the time between child and adulthood "Adolescence begins with the onset of physiologically normal puberty, and ends when an adult identity and behavior are accepted. This period of development corresponds roughly to the period between the ages of 10 and 19 years"[10]. It is a time of heightened vulnerability to many environmental and emotional hazards and a period when the young person's improves their knowledge and their social capacity. Therefore it is important to understand more about adolescents' or teenagers perceptions to climate change and health in order to suggest interventions. In this paper we discuss and suggest strategies that include teenagers as agents in climate change adaptation addressing health.

\section{RESEARCH METHOD}

\subsection{Study design and sample}

This was a survey study designed to assess the perception of climate change with particular focus on the impact on human health among the teenagers. A structured questionnaire used in this survey, modified from previous researchin order to be used with young people. This questionnaire was developed by Climate Change - Mitigation and Adaptation Policies in the health sector (CC-MAP) project [11]. This project supported by Swedish International Development Agency (SIDA) in 2013. In total, the questionnaire consisted of 45 questions. The questionnaire was edited and translated to Bahasa Indonesia. Some questions were deleted as they required a higher level of understanding than could be expected from the respondents. The questionnaire consisted of rating scale questions and multiple choices. Questions addressing respondents' priorities and attitudes, with respect to particular statements, were provided a scale from 1 to 10 Likert items. For multiple choice questions and statements, answers were provided as (X) items from strongly disagree to completely agree, or don't know to Know completely.

\subsection{Participants}

We choose a senior high school in the highlands of Gunungkidul by involving 147 students of aged 16-17 years old from the second grade as population. The second grade was chosen because on this stage the teenagers tend to be growing the mindset and learn a lot from the their environment, it will be easy to inform them about climate change impact on human health since at this age the teenagers have many questions in order to develop of their priorities and value [12].

We took 95 students as the respondent, in order to fulfill at the minimum sample size required for this study which was 78 to $80 \%$ confidence interval. The calculation was performed using Statcalc-EpiInfo. We used Quota sampling in this study. The teacher chose the students' directly in the class randomly until the quota were fulfilled.

\subsection{Ethical consideration}

The respondents were placed in a class room. Prior to the study, we introduced the study and its purpose by a short presentation to the respondents. Those unwilling to participate were free to leave. No interaction among respondents was allowed but respondents were allowed to contact the researcher when they failed to understand a question.

\subsection{Data analysis}

Data were analyzed using SPSS statistical software 17.00 version. We applied descriptive statistics to present quantitative descriptions of the variables (Univariate analysis) by performing proportion, mean and Standard Deviation (SD) for each question.

\section{RESULTS AND DISCUSSION}

\subsection{Results}

The 95 students were selected by the sampling procedure all of them agreed to participate on this research. At the end of data collection, we cleaned up the data and there were 15 respondents dropped out from this research because of the incomplete answer. 80 respondents participating in this study are teenagers 
of age 16-17 years old originated from rural area of Gunungkidul. Respondents were identifiying three biggest problem in the world, that were: Poverty and lack of food, global warming and climate change, poverty and International terrorism, as shown in Table 1. Respondents were defining climate change as the change of temperature, the change from cold to hot, the seasonal change, extreme event, etc.

Table 1. Problems which Identified as Very Important (Grade 10)

\begin{tabular}{lccc}
\hline \multicolumn{1}{c}{ Problems } & $\%$ & Mean & SD \\
\hline International terrorism & 16.3 & 6.09 & 2.70 \\
Poverty, lack of food & 20 & 6.46 & 3.02 \\
Increasing of elderly & 7.5 & 4.38 & 3.02 \\
Infection disease & 7.5 & 6.38 & 2.36 \\
Global economic crisis & 6.3 & 5.71 & 2.78 \\
Global warming and climate change & 17.5 & 5.90 & 3.03 \\
War and nuclear & 5 & 5.58 & 2.53 \\
Modernization and Globalization & 7.5 & 5.58 & 2.96 \\
\hline
\end{tabular}

Respondents reported have somewhat knowledge about the cause of climate change (76.2\%), the consequence of climate change (53.8\%) and the coping of climate change impact ( $57.5 \%$ ), as shown in Table 2.

Table 2. Respondent Knowledge about Climate Change

\begin{tabular}{lccccr}
\hline Problems & $\begin{array}{c}\text { Don't } \\
\text { know }\end{array}$ & $\begin{array}{c}\text { Somewhat } \\
\text { knowledge } \\
\%\end{array}$ & $\begin{array}{c}\text { A lot of } \\
\text { knowledge }\end{array}$ & Mean & SD \\
\hline Cause of climate change & 20 & 76.2 & 3.8 & 1.84 & 0.46 \\
Consequence of climate change & 41.2 & 53.8 & 5 & 1.64 & 0.57 \\
Effort to coping climate change & 38.8 & 57.5 & 3.7 & 1.65 & 0.55 \\
\hline
\end{tabular}

Most of the respondents felt the impact of climate change now (65\%) and just few percent reported in the next 20-50 years and almost 29\% answered don't know.

Table 3. When the World Will Start Facing Climate Change

\begin{tabular}{lccc}
\hline \multicolumn{1}{c}{ Time frame } & $\%$ & Mean & SD \\
\hline Now & 65 & & \\
In the next 10 years & 3.8 & 3.13 & 3.15 \\
In the next 50 years & 2.5 & & \\
Don't know & 28.7 & & \\
\hline
\end{tabular}

Mostly respondents were given similar opinion (disagree) on the statement regarding the climate change and impact, it was seen from the standard deviation from the mean. On the other hand, there were interesting answer in the statements the increasing of cardiovascular diseases is caused by climate change $(55 \%)$ of respondent disagreed with this statement.

Table 4. About Climate Change and Health. Respondents were Reporting DISAGREED with the Statement

\begin{tabular}{lccc}
\hline \multicolumn{1}{c}{ Statements } & $\%$ & Mean & SD \\
\hline CC is an unstoppable process & 47.5 & 1.55 & 0.54 \\
CC caused by human & 13.8 & 1.93 & 0.44 \\
We can not do anything to stop CC & 73.8 & 1.41 & 0.74 \\
CO2 just has a little impact on CC & 57.5 & 1.64 & 0.81 \\
CC impacts will influence humans only in the long term & 53.8 & 1.56 & 0.67 \\
The increasing of cardiovascular disease is caused by CC & 55 & 1.53 & 0.63 \\
CC is caused by a natural process & 60.0 & 1.48 & 0.63 \\
CC evidence is not convincing & 72.5 & 1.38 & 0.66 \\
\hline
\end{tabular}

Most of the respondents had a fair overall understanding of climate change and its impact to human health; nevertheless there was a lower understanding for the impact on particular diseases, such us in 
cardiovascular (table 4). More than $50 \%$ of respondents agreed with statement on climate change and health with the distribution of the knowledge quite similar, it is seen from the low standard deviation, as shown in Table 5 .

Table 5. Climate Change and Impact in Health. Respondents that AGREED with the Statement

\begin{tabular}{lccc}
\hline \multicolumn{1}{c}{ Statements } & $\%$ & Mean & SD \\
\hline CC has an impact on health & 73.8 & 1.45 & 0.79 \\
There are victims of CC due to extreme weather & 88.8 & 1.98 & 0.31 \\
CC is influencing human mental health & 56.3 & 1.69 & 0.58 \\
CC is increasing diseases spread by food and water & 67.5 & 1.85 & 0.55 \\
CC is increasing the incidence of infectious diseases & 83.8 & 1.94 & 0.40 \\
such as Dengue and Malaria & & & \\
\hline
\end{tabular}

Respondents identified the three important media as source of climate change information, namely: talking with the family, from mass media (radio and television) and the last was an internet, as shown in Table 6.

Table 6. The Most Information Source of Climate Change

\begin{tabular}{lc}
\hline \multicolumn{1}{c}{ Information source } & $\%$ \\
\hline Family & 30.0 \\
Mass media (radio, tv) & 25.3 \\
Internet & 18.8 \\
\hline
\end{tabular}

\subsection{Discussion}

This is the first study of its kind in South East Asia looking into teenager's perceptions of climate change and health. The results can be used to start building hypothesis that can be studied further in future studies.

Our study suggests that teenagers are already relatively well aware of climate change and its impact on human health. It's seen from table 5 that $73.8 \%$ of respondent agree that climate change give impact on human health. In general, respondents identified some important problems in the world of particular concern; global warming, climate change, poverty and lack of food. This is in line with previous research that demonstrating that low income citizens are vulnerable to climate variability in relation to agricultural activity and the decreasing crop yield [13],[14]. Respondents also seemed to have a general knowledge about "climate change" as a phenomenon with climate change having a relationship with temperature, humidity, weather and global warming. It is consistent with research conducted by the International Energy Agency reporting that climate change is a change in regional temperature, precipitation and extreme weather [15]. However, when they were asked about the cause, the consequence and effort to coping of climate change they answered mostly respondents answered with have somewhat knowledge about. This suggests that although respondents understand the terminology of climate change they don't understand climate change in depth. The majority of respondents explained climate change as changing from cold to hot or the change of weather; in other word the respondent knowledge limited on daily climate variability.

Most of the respondents answered that they had felt the impact of climate change in recent days; the temperature weather was hotter and they sometimes had experienced extreme weather like tornados. The majority of the respondents placed the seriousness level of climate change as a 5 on a scale from 1 to 10 . Furthermore, they disagreed with the statement that climate change can't be stopped and that it is caused only by natural processes. It means that respondents are already aware that humans have a role in the changing of the climate. This is consistent with the findings by the Environmental Protection Agency (EPA) [16] and The Intergovernmental Panel on Climate Change (IPCC) that climate change is driven by human activity [2].

When respondents were asked about climate change and health, most of the respondents agreed that the changing climate had an impact on human health, particularly with respect to extreme weather events and infectious diseases. In Gunungkidul, particularly in Gedangsari sub district, the inhabitants has been exposed several times by some extreme weather events like storms (tornados) and landslides due the high intensity of rainfall [17],[18]. But respondents appeared not to understand that non-communicable diseases like cardiovascular could be caused or aggravated by climate change. Even though, the evidence state that climate change will threat mental health[19],[20], respiratory disease [21], cardiovascular disease and stroke [6]. 
One interesting finding from this research is regarding the information sources that teenagers use to learn about climate change. The three top ranking sources of information chosen by the respondents were; family, mass media (radio and television) and the internet. This finding can guide decision makers and health professionals when determining what tools and methods to use to communicate about climate change with young people and when developing strategies aiming to increase the awareness and resilience of the young community to withstand its impacts. For example counseling to the community (delegation from each household) about the impact of climate change on health can be provided [22]. Another strategy would be to offer training for teenagers including ways to communicate climate change impacts on human health to households or to peer group; different ways using the mass media, like how to write internet blogs and debates in newspapers and/or social media.

In line with this the role of adolescents as promoters in the health sector has been tested in Tanzania for HIV AIDS prevention [23] with good results which could also be applied in this context. The hypothesis from this study is that young people need to be informed about climate change and its impacts on human health and that should be spread via internet, magazines, newspapers, television, radio and other mass media to increase the understanding of the teenagers [24]. Many studies have found that teenagers are easily affected by television and internet (mass media) [25]. Consequently, we propose to empower teenagers as agents of change to anticipate and communicate the impact of climate change on health. This would benefit society as they are important agents that can both inspire positive changes in the community, such study in HIV AIDS by using youth as agent of change [26].

Unluckily, this study is limited by the low number of respondents and the convenience sample. Hence, the results must be interpreted with some caution. However they generate hypotheses which through discussion with already existing evidence in this field can guide the creation of intervention strategies. As there are no such previous studies in South East Asia this study can serve as a starting point for designing intervention strategies and for future research.

\section{CONCLUSION}

In summary, climate change perceptions among this sample of teenagers can be categorized as intermediate. They were aware of human activities as the main cause of climate change, were rather well aware of the implications for human health. However, they believe that the climate change process can stop, this statement be supported by the next statement that mostly of respondent agree that they can do something to stop climate change process. Teenagers can be good agents of change [27] to prevent the impact of climate change on human health because teenagers have ineffective interpersonal communication skills [28] and are also open minded (easily influenced by external factors). Consequently, this will be beneficial to improve the teenager's perception regarding climate change impact on human health. To prevent the impact of climate change on health by using teenagers as agents of change we propose to facilitate interpersonal communication skill by designing and conducting training programmes [28]. For example, we suggest involving teenagers in short courses and community campaigns, or including information about climate change and its short- and long term impacts in the school curriculum.

\section{ACKNOWLEDGEMENTS}

This study was financed by the Faculty of Public Health, Ahmad Dahlan University, Yogyakarta, Indonesia. The authors are grateful to all civitas academic of vocational senior high school of SMK 1 Gedangsari, Gunungkidul for succeeding survey.

\section{REFERENCES}

[1] Satterthwaite D., "Climate Change and Urbanization: Effects and Impliactions for Urban Governance," United Nations Expert Group Meeting on Population Distribution, Urbanization, Internal Migration and Development, New York, 21-23 January 2008.

[2] WHO, "Comment Climate Change And Health: on the Latest IPCC Report," Elseveir, vol/issue: 6736(14), pp. 1-5, 2014.

[3] Anderson J., Bausch C., "Climate Change and Natural Disasters: Scientific evidence of a possible relation between recent natural disasters and climate change," London, 2006. Corvalan C, Hales S, McMichael A., "Ecosystems and Human Well - Being: Health Sysnthesis," Geneva, 2005.

[4] Corvalan C., Hales S., McMichael A., "Ecosystems and Human Well - Being: Health Sysnthesis," Geneva, 2005.

[5] Kaltenbach M., Maschke C., Klinke R., "Health Consequences of Climate Change," London, 2008. 
[6] Portier C. J., Thigpen T. K., Carter S. R., et al., "A Human Health Perspective On Climate Change: A Report Outlining the Research Needs on the Human Health Effects of Climate Change. Research Triangle Park," NC: Environmental Health Perspectives/National Institute of Environmental Health Sciences, 2010. doi:10.1289/ehp.1002272 Available: www.niehs.nih.gov/climatereport.

[7] Haines A., Kovats R. S., Campbell L. D., Corvalan C., "Climate change and human health: impacts, vulnerability and public health," Public Health, vol/issue: 120(7), pp. 585-96, 2006. Available from: http://www.ncbi.nlm.nih.gov/pubmed/16542689.

[8] Epstein P. R., "Climate change and emerging infectious diseases," Microbes Infectious, vol/issue: 3(9), pp. 747-54, 2001. Available from: http://www.ncbi.nlm.nih.gov/pubmed/11489423.

[9] Oxford University Press, "Teenagers [Internet]," Web. 2015 [cited 2015 Aug 28]. p. 1. Available from: https://www.google.co.id/webhp?sourceid=chrome-instant\&ion=1\&espv=2\&ie=UTF-8\#q=adolescent.

[10] Adolescent Health Committee, "Age limits and adolescents," Paediatric Child Heal, vol/issue: 8(9), pp. 9397, 2003.

[11] Ng N., "Perception about climate change and the role of health professionals: A pilot study in Yogyakarta Province," Yogyakarta, 2013.

[12] Public Health Agency of Canada, "ARCHIVED - Because Life Goes On. Helping Children and Youth Live With Separation and Divorce - Section 4 [Internet]," Web. 2015 [cited 2015 Aug 24]. p. 1. Available from: http://www.phac-aspc.gc.ca/publicat/mh-sm/divorce/4-eng.php.

[13] Fussel H. M., "Who is most affected by the impact of climate change," in: Ludermann B, editor, "Climate Change and Poverty: A challenge for a fair world policy," Frankfurt, Welt Sichten, pp. 7-8, 2008.

[14] Correct citation: Vermeulen S. J., "Climate change, food security and small-scale producers. CCAFS Info Brief. CGIAR," Research Program on Climate Change, Agriculture and Food Security (CCAFS), Copenhagen, Denmark, 2014. Available online at: www.ccafs.cgiar.org.

[15] International Energy Agency, "Climate Change [Internet]," 2014 [cited 2015 Apr 16]. Available from: http://www.iea.org/topics/climatechange/.

[16] EPA, "Causes of Climate Change [Internet]," 2014 [cited 2014 Mar 1]. p. 1. Available from: http://www.epa.gov/climatechange/science/causes.html.

[17] Sunartono, “Angin puting beliung, 15 rumah rusak parah," Harian Jogja, Solopos [Internet], Gunungkidul, 2011 Jul 13, pp. 1. Available from: http://gaul.solopos.com/angin-puting-beliung-15-rumah-rusak-parah-150241.

[18] Suharjono, Kuntadi, Linangkung E., Setyawan P., Anshori R., "Rentetan Bencana Landa DIY," Koran Sindo [Internet], Gunungkidul, 2015 Jul 17, pp. 1. Available from: http://www.koransindo.com/read/963933/151/rentetan-bencana-landa-diy-1423802417.

[19] Hanna E. G., Kjellstrom T., Bennett C., Dear K., "Climate change and rising heat: population health implications for working people in Australia," Asia Pacific Journal of Public Health, vol/issue: 23(2 Suppl), pp. 14S - 26, 2011.

[20] National Center for Environmental Health, "Mental Health and Stress-Related Disorders [Internet]," Climate change and health, pp. 1, 2014. Available from: http://www.cdc.gov/climateandhealth/effects/mental_health_disorders.htm.

[21] D’Amato G., Cecchi L., D’Amato M., Annesi-Maesano I., "Climate change and respiratory diseases," European Respiratory Society, vol/issue: 23(132), pp. 161-9, 2014. Available from: http://www.ncbi.nlm.nih.gov/pubmed/24881071.

[22] Shea K. M., "Global climate change and children's health," Pediatrics, vol/issue: 120(5), pp. e1359-67, 2007. Available from: http://www.ncbi.nlm.nih.gov/pubmed/17967924.

[23] Kamo N., Carlson M., Brennan R. T., Earls F., "Young citizens as health agents: Use of drama in promoting community efficacy for HIV/AIDS," Amerian Journal of Public Health, vol/issue: 98(2), pp. 201-4, 2008.

[24] Kakade O., Hiremath S., Raut N., "Role of Media in Creating Awareness about Climate Change- A Case Study of Bijapur City," IOSR Journal Of Humanities And Social Science, vol/issue: 10(1), pp. 37-43, 2013.

[25] IOM (Institute of Medicine) and NRC (National Research Council), "The Science of Adolescent Risk-Taking: Workshop Report," Committee on the Science of Adolescence, Washington, DC, The National Academies Press, 2011.

[26] Pearlman D. N., Camberg L., Wallace L. J., Symons P., Finison L., “Tapping youth as agents for change,” Journal Of Adolescent Health, vol/issue: 31(1), pp. 31-9, 2002.

[27] Burke A., Hughes J., Hardware S., Thompson S., "Education Matters," Volume 2, Issue 1, 2014. Educ Matters, vol/issue: 1(2), pp. 65-87, 2013.

[28] Grobler S., Myburgh C. P., Poggenpoel M., "Adolescent interpersonal communication patterns," Curationis, vol/issue: 22(4), pp. 35-40, 1999. 


\section{BIOGRAPHIES OF AUTHORS}

\begin{tabular}{|l|l|} 
Sulistyawati which is considered as a lecturer in Department of Public Health, Universitas \\
Ahmad Dahlan. She was born in Gunungkidul, Yogyakarta, Indonesia on May02, 1983. She \\
graduated from Faculty of Geography, Universitas Gadjah Mada 2007, and finished her Master \\
in Health Management Information Systems, Universitas Gadjah Mada at 2012. Then after in \\
2014 she registered as a PhD student at Umea University, Sweden. Sulistyawati havea major \\
interest in socio-demographic, geography information system, infectious disease and climate \\
change. Many publications produced regarding her interest.
\end{tabular}

